\title{
Power Representation in Cigarette Ads Djarum 76 Election Series
}

\author{
Altinoga Ibnu Sina $\mathrm{S}^{1}$, Setyo Budi², and Ahmad Adib ${ }^{3}$ \\ \{altinoga.i.s.s@gmail.com ${ }^{1}$,setiobudi@staff.uns.ac.id ${ }^{2}$, ahmadadib.solo@staff.uns.ac.id ${ }^{3}$ \} \\ 1,2,3 Universitas Sebelas Maret, Surakarta, Indonesia
}

\begin{abstract}
In Indonesia in 2019 is the year of the Democratic Party a lot of advertising that themed the elections one of Djarum's ad 76 election version in the advertisement describe how an advertisement not only works for manufacturers to introduce A product to the consumers, but thinking about a new function as ads that have the power of social criticism by using humor satire as aired in the ad version Djarum 76 elections. This research was conducted by the method of semiotic analysis to explain the meaning or symbol contained in the ad Djarum 76 Version election. In this study it was found that ads created by Djarum 76 has Other Functions power of social criticism as well as benefits for the advertising of tobacco products Djarum another, and in this ad many functions mark must be interpreted in this case meets the theory of semiotic analysis of Roland Barthes by using theory representation of Stuart Hall.
\end{abstract}

Keywords: Advertising, Communication, Djarum 76, Power Representation

\section{INTRODUCTION}

In Indonesia in 2019 is the year of the democratic party a lot of ads with the theme of the election one ad Djarum 76 version: want to become parliamentary candidates are intelligent and want to be a clever parliamentary candidates, the previous versions of the ad Djarum 76 still retains his trademark with raised characters genie in Java, as well as in the ad version of this election.

Media Television is the best option for most advertisers in Indonesia. Television is one highly effective communication medium to provide information compared to other media advertising or advertising is pre-promoted as a promotional activity [1]. Excess television media in conveying the message is the message conveyed through pictures and sounds simultaneously, as well as providing an atmosphere of life so it is easily accepted by the audience. The television broadcast also possess a direct, simultaneous, intimate, and real [2].

The power that is owned by television as a tool with a large system capable of creating a very high excitatory power in the influence of attitudes, behavior and mindset of its character, which eventually led to a large number of changes in Community [3]

Code, sign, or message contained in the ad is the content of the ad forming elements. These elements are the elements that make an ad has a meaning that is capable of "bewitching" the audience to consider the use of the product as well as direct the audience's perspective that can be constructed in accordance with the needs or interests of certain parties, 
in this case is the advertisers. Ad Djarum 76 version of "Want intelligent and want to be good at" besides affixing the element of humor, the ad even this provides interesting elements by lifting the legislative candidates in Indonesia as an icon and use the attributes official who is characteristic of the device from the government, which clearly proves the Ad Djarum 76 in a packed ad are loaded with social criticism into a parody ad that can be digested consumer

In his book A Theory of Semiotics. Semiotics developed Eco directed to a process in which culture produces signs or connect the meaning of the sign. Although for Eco meaning production is a social activity, he allow subjective factors involved in each individual action in committing semiotic. The nature of the code itself, which is arbitrary, explaining how the code could be. by manipulating the marker, [4]. The signs only carry a signifiant meaning in relation to the reader. It is the reader who connects the mark with what is signifiphit in accordance with the Convention in the language system in question [5].

\section{METHOD}

This research is descriptive qualitative with the main focus on describing and explaining the representation in advertising Djarum 76 series of elections in which contains a lot of visual symbols therein. The main data source is Ad Djarum 76 series of elections. Technique data collecting use observation and in-depth interviews with experts and practitioners. Data triangulation is used to check the validity of the data by utilizing other matters [6]. Triangulation technique used is the triangulation of data sources and theories. Data were analyzed using analysis of interactive chain with measures including data collection, data reduction, data presentation, and conclusion.

\section{RESULT AND DISCUSSION}

In Indonesia in 2019 is the year of the democratic party a lot of ads with the theme of the election one ad Djarum 76 version: want to become parliamentary candidates are intelligent and want to be a clever parliamentary candidates, the previous versions of the ad Djarum 76 still retains his trademark with raised characters Jin Java, It has an endomorphic type, which is humorous, casual and ingenious [7], as well as in the ad version of this election.

Visualization of cigarette advertising Djarum 76 version: Want to be smart at the start by showing the scene where in it there are journalists who are pursuing candidates, asking "Flooding how to pack, litter, congestion, poverty solution how to pack?", And then he ran legislative candidate is entered stumbled into the room and then came the genie pot of java "Weii ask what? Then legislative candidates are saying "So candidates intelligent", and while looking at the contents of the head of candidates the genie said "OK", but this would be the darkness of night to the sound of crickets, "Crickets empty brain so Impossible so Krik Krik and ending with" The important thing is intelligent "

Followed by advertising Djarum 76 version: Want So intelligent "Love clubbing" begins by showing a scene where in it there are only 2 players are candidates for legislative and Jinn Java, starting with dialogue by genie "Ask what", then legislative candidates are saying " so candidates intelligent ", and while looking at the contents of the head of candidates the genie said" OK ", but this time seen in the content of the head of candidates was when he was clubbing with her while enjoying the music, then the genie said," the dream of the brain clubbing so, impossible, impossible, impossible "and ending cover of" The important thing is clubbing ".

Followed by the next series advertisement Djarum 76 version: "Want So Clever" begins by showing a scene where in it there are only 2 players are candidates for legislative and Jinn 
Java, starting with dialogue by genie "Ask what", then legislative candidates are saying " so candidates clever ", and while looking at the contents of the candidate's head Jin said" OK ", but this time of the visits is a television broadcast that already completed in the 90s off-air broadcast, then the genie said brain dreams ... tit tit ... so impossible. Ends with the word "important tiiittt".

"An advertisement would not exist without the message. The message conveyed by an advertisement to form a blend of verbal and non-verbal messages. Verbal message is the message delivered either orally or in writing. While the non-verbal message is a visual form and color are presented in the ad. Throughout the form of non-verbal means, then it can be termed as a communication message "[8].

When viewed from the description above a lot of visual representations contained therein herein researchers will analyze the impact of visual representation in the advertisement Djarum 76 series of elections.

\subsection{Message Ad Djarum 76 Version Want to be a Clever Parliamentary Candidates}

Visualization of cigarette advertising Djarum 76 version: Want to be smart at the start by showing the scene where in it there are journalists who are pursuing candidates, asking "Flooding how to pack, litter, congestion, poverty solution how to pack?", And then he ran legislative candidate is entered stumbled into the room and then came the genie pot of java "Weii ask what? Then legislative candidates are saying "So candidates intelligent", and while looking at the contents of the head of candidates the genie said "OK", but this would be the darkness of night to the sound of crickets, "Crickets empty brain so Impossible so Krik Krik and ending with" The important thing is intelligent "

In the visualization of the meaning contained Behavior, and said the genie is in conformity with social status. Jin who have lower social hierarchy, respect men who took it out of a jug. The man was served as host of the genie. Like the master that must be served, then the genie behaves respectfully to the inventor by behaving politely like Javanese people, and allows the manners of the Java language, which is refined manners. However, when the man was told his request to change the social hierarchy Jin. The position of the social hierarchy Jin becomes higher. Jin started being arrogant. Jin also use an equivalent ngoko when answering a request from the master. Demand from the legislative candidates answered with the words "cricket". Crickets empty brain so Impossible so Krik Krik,

Demand from the legislative candidate was not granted by a genie. This reflects the philosophy of the Javanese expressed by Patria [9] i.e., inggah inggih kepanggih ora. After saying "OK" but after that also said "impossible".

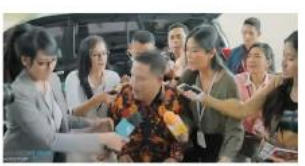

scene 1

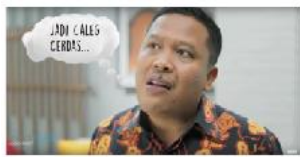

scene 5

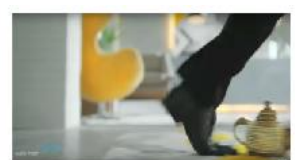

scene 2

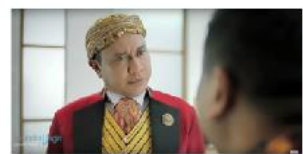

scene 6

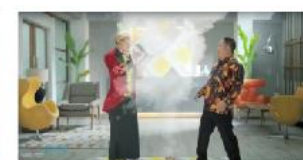

scene 3

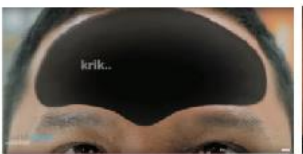

scene 7

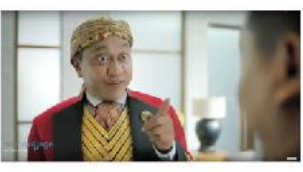

scene 4

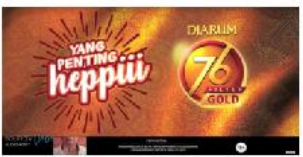

scene 8 
Fig. 1. Ad Djarum 76 Pieces Scene Version "Want So Smart"

\subsection{Message Ads Djarum 76 Versions Parliamentary Candidates. wanted so Clever ( Clubbing )}

Visualization of advertising Djarum 76 version: Want So intelligent (clubbing) begins by showing a scene where in it there are only 2 players are candidates for legislative and Jin Java, starting with dialogue by genie "Ask what", then legislative candidates are saying "So candidates intelligent ", and while looking at the contents of the head of candidates the genie said" OK ", but this time seen in the content of the head of candidates was when he was clubbing with her while enjoying the music, then the genie said," the dream of the brain clubbing so, impossible, impossible, impossible "and ending cover of" The important thing is clubbing ".

This time Jin said "ngimpiii" clubbing brain so, emphasizing that it is a form of humor. Humor used in this ad belongs to the humor theory of superiority, and legislative candidates and underestimate brain looks just like clubbing alone. It can also be seen from the scene 2 there are moles that are in the mouth, based on knowledge titen in kejawen [10] which indicates that the person is just a lot of talk, but his brain is empty.

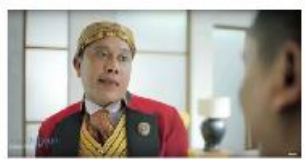

scene 1

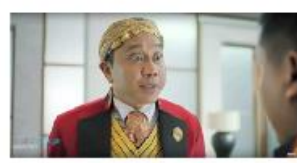

scene 5

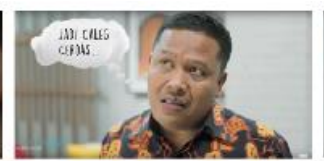

scene 2

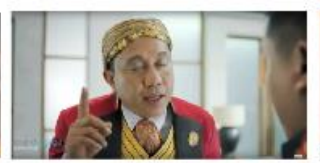

scene 6

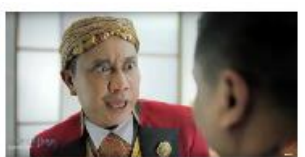

scene 3

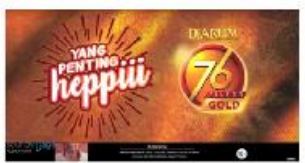

scene 7

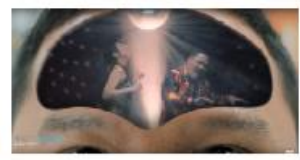

scene 4

Fig. 2. Ad Djarum 76 Pieces Scene Version "Want So Smart Brain clubbing"

\subsection{Message Ads Djarum 76 Version legislative Candidates wanted so clever.}

Followed by the next series advertisement Djarum 76 version: "Want So Clever" begins by showing a scene where in it there are only 2 players are candidates for legislative and Jinn Java, starting with dialogue by genie "Ask what", then legislative candidates are saying " so candidates clever ", and while looking at the contents of the candidate's head Jin said" OK ", but this time of the visits is a television broadcast that already completed in the 90s off-air broadcast, then the genie said brain dreams ... tit tit ... so impossible. Ends with the word "important tiiittt".

In the ad there are visualizations Djarum 76 series depicting the brain of the legislative candidates as television broadcasts off the water, can be interpreted as the completion of a broadcast that is identical to the sound of "tittttttt" indicating that it's not their activities in the broadcast. Just as the brain of candidates who have been unable to think anything blank. 


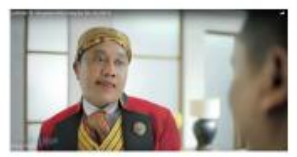

scene 1

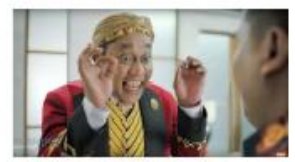

scene 5

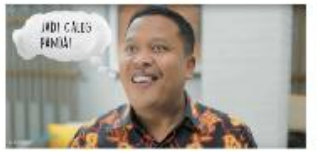

scene 2

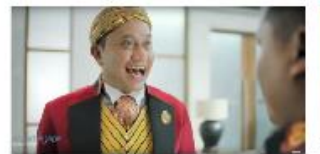

scene 6

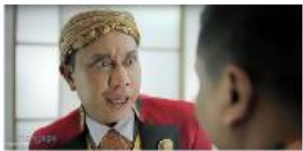

scene 3

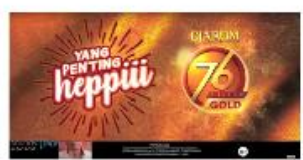

scene 7

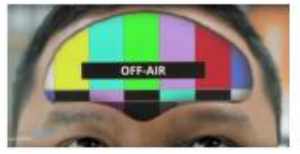

scene 4

Fig. 3. Ad Djarum 76 Pieces Scene Version "Want So Clever".

According to the functional theory, society is a social system which consists of parts or elements which are interrelated and integrated in the balance. The changes that occurred in a section will bring changes also to other changes [11]. In this case if it is related to the phenomenon advertising Djarum 76 version of the current election, rent by Danesi [12], "Ad contains public announcements, promotions, sponsorship, or endorsement of products, services, business, a person, an event, and others in order to attract or increase interest The message also has the meaning of repeated things [13]. Currently, the ad has been turned into the dominant form of social discourse affects lifestyles, worldviews, economic systems, political and even traditional values, because it is designed to show how people can best meet their needs and achieve their goals. "Ads that show lifestyle, trends, and social values embraced by a society are believed to increase sales. In this way it blurs the line between usevalue products with a social conscience. Additionally advertising is an apparatus to reframe the meaning for adding value to a commodity [14].

But ad today not only as a means to introduce a product to consumers, but of visual semiotics itself give rise to an effective power of social criticism and can be digested by the public through advertisement satire humor. It is also closely related to how we understand our environment and each other. Comprehension is produced through a complex mix of backgrounds, tastes, fears, training, trends, and experience, all made real to us through the principles and processes of representation that frame, and adjust our experiences are in the world. What we see is not what is, but what socio-cultural traditions, and the context of seeing it [15] [16].

Future studies could examine the semiotic metaphor shown in this ad, so that researchers can then understand what the advertiser wishes to provide through the representation of language in the ad Djarum 76.

\section{CONCLUSION}

This multimedia show visual semiotic in advertising Djarum 76 series of elections, Ad Djarum 76 has become a social critique in the form of vague allusion to build a new metaphors in the mind of the audience so visual form of advertising is not to criticize directly, but the audience are building the world of images in his mind respectively.

This proves the success of Ad Djarum 76 in a packed ads that are loaded with social criticism into an ad parody that can be enjoyed by audiences without giving the impression of 
sarcasm that bear on public complaints as well as complaints from other parties related to the culture and attributes used in the ad.

\section{REFERENCE}

[1] Wibowo, W. Semiotika Komunikasi: Aplikasi Praktis Bagi Penelitian dan Skripsi Komunikasi. Jakarta: Mitra Wacana Media. 2011.

[2] Mulyana, D. Bercinta dengan Televisi. Bandung: PT Remaja Rosdakarya. 1997.

[3] Sumartono. Terperangkap dalam Iklan. Bandung: Alfabeta. 2002.

[4] Eco, U. The Role of The Reader. Indiana University Press: Bloomington. 1977.

[5] Sobur, A. Analisis Teks Media , Bandung: Rosdakarya. 2009.

[6] Moleong, L. J. Metodologi Penelitian Kualitatif (Edisi Revisi). Bandung: PT Remaja Rosdakarya. 2014.

[7] Cangara, H. Pengantar Ilmu Komunikasi. Jakarta: PT. Raja Grafindo Persada. 2005.

[8] Widyatama, R. Pengantar Periklanan. Jakarta: Buana Pustaka Indonesia. 2005.

[9] Patria, A. S. Iklan Djarum 76 Tema Jin: Kajian Struktur dan Makna. 2011.

[10] Geertz, C. Agama Jawa: Abangan, Santri, Priyayi dalam Kebudayaan Jawa. Jakarta: Komunitas Bambu. 2013.

[11] Ritzer, G. Sosiologi Ilmu Pengetahuan Berparadigma Ganda, terj Alimandan. Jakarta: Rajawali. 1985.

[12] Danesi, M. Dictionary of Media and Communications. London: M. E. Sharpe. 2009.

[13] Danesi, M. Pesan, Tanda, dan Makna: Buku Teks Dasar Mengenai Semiotika dan Teosi Komunikasi. Yogyakarta: Jalasutra. 2010.

[14] Fletcher, W. Advertising a Very Short Introduction. New York: Oxford University Press. 2010.

[15] Webb, J. Understanding Representation. London: SAGE Publication Ltd. 2009.

[16] K. Saddhono, "Language of Coastal Communities in the Northern Coast of Central Java: Sociolinguistic Studies in Cultural Integration Maritime-Agrarian Perspective." Adv. Sci. Let. vol. 23 no. 10 pp 10054-10056, 2017 